\title{
The Equilibrium on Money Market and the Central Bank Issuing Policy ${ }^{1}$
}

\author{
Richard Pospíšil ${ }^{2}$
}

\section{Faculty of Arts, Palacký University Olomouc, Czech Republic email: richard.pospisil@upol.cz}

POSPÍŠIL, Richard. The Equilibrium on Money Market and the Central Bank Issuing Policy. International and Comparative Law Review, 2015, vol. 15, no. 1, pp. 141-152. DOI: 10.1515/iclr-2016-0032.

\begin{abstract}
The issue of money and establishing interest rates are the main activities of central banks. Through this, the banks immediately influence the behaviour of households, companies, financial markets and the state with the impact on real outcome, employment and prices. When monitoring the issue of money, it is necessary to focus not only on its volume, but also on the attributes and functions carried by money. Among the first economists who considered the quality monetary aspect were J. Locke, D. Hume, D. Ricardo and others. The founders of modern monetarism of the $20^{\text {th }}$ century were I. Fisher and M. Friedman. Fisher was the first to define the equation of monetary equilibrium in the present-day form. The objective of the paper is to point out different approaches to the equation and its modifications and different meanings of its variables. As regards the monetary aggregate $\mathrm{M}-$ Money - the paper also deals with the denomination of the aggregate to its various elements, which is significant for fulfilling monetary policy targets. This approach is very important especially at present in the time of crisis when central banks are performing their policy considering contradictory targets of price stability and economic growth.
\end{abstract}

Keywords: Finance, financial law, issue of money, monetary policy, monetary equilibrium, monetarism, Irving Fisher

\section{Introduction}

The current economic crisis is primarily a budget and debt one. Nevertheless, together with public budgets and public debts, the issues of monetary policy have been continually and broadly discussed and thought out. Central banks issue money and govern short-term interest rates and thereby influence the behaviour of financial markets, wealth, real outcome, employment and also prices.

1 Work on this paper was supported by the grant from Faculty of Arts, Palacký University Olomouc, IGA_FF:2015_014, Continuities and Discontinuities of Economy and Management in the Past and Present.

2 Assoc. prof. Richard Pospišil, Ph.D., Department, Faculty of Arts, Palacký University, Olomouc, Czech Republic, e-mail: richard.pospisil@upol.cz. 
Even after several decades of real functioning of central banking it is possible to find a schematic simplifying of monetary policy, the consequence of which is that the monetary approach has been increasingly oversimplified and mixed up with the regulation of the amount of money in the economy. Other aspects of monetary policy, especially the functioning and attributes of money, its velocity of turnover or the use of regulations of short-term interest rates, have been missed out - maybe due to a difficult and sometimes ambiguous understanding of their content. Money in circulation needs to be monitored not only from the point of view of its volume, but also from the point of view of the functions it carries.

\section{Objectives and Methods}

The objective of the paper is to analyse the monetary equilibrium using the so-called equation of exchange, to analyse the content and characteristics of particular variables of the equation and to define basic methodical resources of monetary equilibrium for the purpose of real implementation of monetary policies by central banks. The predominant methods used were the research and analysis of available historical and current scholarly and scientific resources related to this issue, including their comparison.

\section{Views on the Theory of Money}

The first views related to the quantity monetary thinking appeared more than four centuries ago in connection with the increasing inflow of gold and silver from overseas to Europe. Several philosophers of that time noticed that together with the growth of gold and silver in circulation, prices also grew up.

The first one who tried to give scholarly reasons for the quantity approach to money was the English philosopher, economist, state theorist and jurist John Locke. In 1691, he summed up his interpretation of money supply and its functioning in circulation in five chapters of his pamphlet "Some Considerations of the Consequences of Lowering the Interest and Raising the Value of Money". As an economist - mercantilist he resulted from the generally widespread and accepted identification of money and precious metals. In consequence of precious metal imports to Europe and the increasing mining of precious metals on European fields, he asked himself the question of how much money should actually be in circulation. Even at that time he mentions that it is difficult to define the exact and ideal supply of money in circulation as its function in the economy is affected not only by its volume but also by the velocity of its turnover ${ }^{3}$.

Moreover, Locke assumes that not all the money in circulation really circulates; a part of money is kept for the so-called bad times, or can be taken abroad.

3 BARBON, N. A discourse concerting the new money lighter: in answer to Mr. Locke's Considerations about raising the value of money. McMaster University Press, Canada, 1971, s. 213. 
Related to this, he was the first to suppose that the decrease of money has no significant impact on monetary circulation as it is equalled by faster turnover of money. At the very beginning of his paper he divides money into its particular forms according to the purpose of its use and the velocity of turnover, i.e. money for landholders, money for labourers and money for brokers. Therefore he was the first to discuss the issue of money denomination into particular monetary aggregates, which has been very topical and discussed so far.

Fifty years later the Scottish enlightenment philosopher and economist David Hume became the first true author of the quantity theory of money in the present-day meaning. He sophisticatedly connected the conclusions and findings of many of his predecessors into a united social and economic theory. He published his views in the volume "Political Discourses" in 1752. Pricing is not related only to the value ratio of precious metals, or metal money, and goods, but it is significantly affected by the supply of money in circulation. Increasing the supply of money leads to the increase of prices and to the increase of outcome only in a short-term perspective, whereas in the long-term perspective the real product remains unchanged. In his work "Four Dissertations", which was published as a part of "Essays and Treatises on Several Subjects" in 1757, Hume argues that increasing the supply of money has no other impact than increasing the price of work and goods. In the process towards this change, such increase may have an impact on the economy as it may stimulate industry, but after the changes settle down, there is no impact at all. As the first author he precisely formulated the quantity theory of money and the derived theory of interest rate ${ }^{4}$. Therefore he directly influenced John Maynard Keynes, one of the greatest economists of the $20^{\text {th }}$ century.

David Ricardo was another significant economist who, besides Adam Smith, Thomas Malthus and John Stuart Mill, became one of the most significant representatives of the British school of political economics. In his collection "On the Principles of Political Economy and Taxation" from 1871 he drew the conclusion that the value of money from precious metals is affected not only by its volume but also by the costs of mining the metals and production of money from the metals. On the other hand, the value of paper (non-substance) money, the issue of which was spreading at that time, depends only on its amount. Decreasing the amount can increase its value and vice versa. In Chapter 27 "On Currency and Banks" he discusses the equilibrium of the supply of money in circulation and the amount of offered goods. He also says that any disequilibrium has to be treated by the Bank of England by means of adjustment of its issuing activity. Ricardo united the quantity theory of money and the in-progress theory of value into a comprehensive theory and it is regarded as the peak of the English political economics.

4 FIESER, J. David Hume - Essay, Moral, Political and Literary. 2006, s. 97.

5 SOWELL, T. On classicaleconomics. Yale University Press, USA, 2006, s. 78. 


\section{Equation of Monetary Equilibrium}

The above-mentioned brief overview can be, as most economic relations and associations, summed up into a mathematical equation. At the end of the $19^{\text {th }}$ century some economists attributed its primacy to the well-known American astronomer and economist Simon Newcomb who in his work called "Principles of Political Economy", published in 1885, discusses the "equation of exchange of money and goods" 6 . The first author who published the equation in the form known today was the outstanding American economist Irving Fisher who did so in his work „The Purchasing Power of Money: Its Determination and Relation to Credit, Interest, and Crises", published in 1911. The works of Irving Fisher are considered to be the beginning and basis of monetarism and his notation of the equation is as follows:

$$
\mathrm{MV}=\mathrm{PT}
$$

where $\mathrm{M}$ is the nominal amount of money (in the Czech Republic defined by the Czech National Bank), V is the velocity of money turnover (circulation) which defines how many times during the period in view one Czech crown is on average used for purchasing goods. On the right side of the equation $\mathrm{P}$ defines the average price of goods and services (in this case the price level) and T represents the number of transactions. Fisher is his original version of the equation used $\mathrm{T}$ for expressing all transactions, i.e. for purchasing the final production of goods and services, for purchasing intermediate goods and for purchasing capital transactions, i.e. in a broader sense for purchasing land and capital. In the present-day form $\mathrm{T}$ involves only the final production of goods and services and therefore $\mathrm{T}$ is substituted by $\mathrm{Q}$ (the real product) and the form of the equation is as follows:

$$
\mathrm{MV}=\mathrm{PQ}=(\mathrm{p} 1 \mathrm{q} 1+\mathrm{p} 2 \mathrm{q} 2+\ldots)
$$

Every purchase may be seen as an entry in the double-entry bookkeeping in two different ways. On one hand as the amount of money spent and on the other hand as the amount of goods and services (multiplied by their price) purchased. The left side of the equation represents the supply of money and the right side of the equation represents the supply of goods, or money demand.

According to Fisher, the equation implies the following conclusions:

- $\quad$ prices change direct proportionally to the amount of money in case the amount of purchased goods $\mathrm{Q}$ and the velocity of money circulation $\mathrm{V}$ remain unchanged,

- $\quad$ prices change direct proportionally to the velocity of money turnover (circulation) in case the amount of money $\mathrm{M}$ and the amount of purchased goods Q remain unchanged,

6 FRIEDMAN, M. Za vším hledej peníze. Praha: Management Press, 1997, s. 45. 
- prices change in the opposite proportion to the amount of purchased goods $\mathrm{Q}$ in case the amount of money $\mathrm{M}$ and the velocity of its turnover $\mathrm{V}$ remain unchanged.

From the above conclusions, Fisher also deduced the impact of the change of money on nominal and real quantities. Provided that $\mathrm{V}$ is stable (the economy is in equilibrium and $\mathrm{V}$ is determined by payment conventions and technologies) and $\mathrm{Q}$ is independent on the supply of money in circulation and on price (the economy fully uses its disposable resources and finds itself close to its potential with full employment), the changes in the supply of money in circulation M lead only to the changes of the price level, i.e. an increase of money supply results in the same increase of the price level'.

The logical consequence of the above is the so-called neutrality, or the super neutrality of money, which means that money does not affect the real quantities of the economy (real product and unemployment rate) but only the nominal ones (price level, nominal product, or both). Money is regarded as neutral in case the money supply has no long-term impact on the real interest rate, real product and real monetary rate because the above-mentioned quantities in their nominal amount exchange one to one to the nominal amount of the money supply. The only result of a supply shock on the side of the money supply change (increase) is only the increase of the price level. Money is regarded as super neutral in case that permanent changes of the money supply have no long-term impact on the real interest rates, real product and the rate of its growth and the real monetary rate because the inflation rate and the above-mentioned quantities in their nominal amount change one to one to the nominal amount of the money supply. In this sense, super neutrality is discussed with regard to the real revenue (standard of living) and with regard to the rate of growth of real revenue (economic growth) ${ }^{8}$.

The impact of inflation increase on relative demand for money and capital can be illustrated by the so-called Tobin effect which is based on the premise that a part of the property portfolio of economic entities is both money and physical capital. Increasing the rate of inflation at the given real return of capital leads to the decrease of money attractiveness and increase of capital attractiveness which in consequence leads to the revaluation of portfolio structures. The higher rate of inflation then corresponds with higher stock of capital and in consequence with the increase of real revenue. What also plays a fundamental role is the aversion of households towards saving risks and the legal deposit insurance. In a standard market economy, the rate of inflation and the rate of economic growth are expertly set by the mix of monetary and fiscal policies. Changes of the

7 FISHER, I. The Purchasing Powerof Money: Its Determination and Relation to Credit, Interest, and Crises. New York: The Macmillan, 1922, s. 344.

8 FRAIT, J., ZEDNÍČEK, R. Monetární politika, neutralita a superneutralita peněz. In Bankovnictví, 2001, vol. 18, No. 4., s. 4. 
monetary policy affect the flow of government revenues, which in consequence affects changes in the fiscal policy. If economic entities suffer from high aversion towards risk, then changes in the fiscal policy are manifested by the fact that high rate of inflation is related to slow economic growth (stagflation). If the economic policy is transparent and trustworthy and risk aversion is low, the result may correspond with the presumption of the Tobin effect.

As regards monetary policy, Fisher was the first economist to clearly and consequently distinguish between the real and nominal interest rates. The so-called Fisher effect deals with the change of the real interest rates depending on the amount of the nominal interest rates and inflation. Generally the real interest rates are considered to be nominal interest rates minus inflation. According to Fisher, the mutual relation is more complex. The real interest rate $r$ is defined as follows:

$$
r=[(1+i) /(1+\pi)]-1
$$

Where $i$ is the nominal interest rate and the inflation $\pi$ is the growth rate of the consumer prices index. Fisher explains this relation by the impact of inflation on the economy. Inflation not only depreciates the real revenue of interest rates but primarily distorts the prices of goods and services and therefore, according to Fisher, the real interest rates are lower than what would correspond with the simple margin between the nominal rates and the rate of inflation.

Further development of the quantity theory of money in the $20^{\text {th }}$ century was mostly influenced by two significant economic approaches - Keynesianism and Monetarism.

In the first half of the $20^{\text {th }}$ century the all-round British genius, especially economist and mathematician John Maynard Keynes, the inheritance of whom hugely affected all fields of economics, became the scholastic and ideological founder of the Keynesian thinking. Keynes' book "The General Theory of Employment, Interest and Money" from 1936 became the principal work of the main stream of the economic theory at that time.

Keynes did not limit himself only to work with the above-mentioned macroeconomic aggregates but he worked especially with the aggregate $M$ with regard to its relation to the variables such as unemployment, investment, interest rates, economic growth, budget deficit etc. He treated the aggregate $M$ from a different point of view - he accentuated another attribute of money which is, beside the velocity of its turnover, its liquidity. He viewed the supply of money in circulation as money demand. Keeping different forms of money can have different motives - either money is kept for the purpose of purchasing goods and services - i.e. the transaction (circulation) motive, or it is kept for the reserve purpose - i.e. the canniness motive, or the hoarding motive (reserve). Based on this we can see that particular forms of money (kept for particular purposes) differ significantly depending on their liquidity. Transaction money (the circulation motive) has

\footnotetext{
(C) Palacký University Olomouc, Czech Republic, 2015. ISSN 1213-8770 (print), ISSN: 2464-6601 (online).
} 
a cash or undated form in contrast with money kept as a reserve (the canniness motive) which usually has the form of time deposit or money kept as a monetary asset. And the size, intensity and preference of these motives determine the level of money liquidity, or: an asset is the more money, the more it is liquid, and it is the more liquid, the lower are the costs related to its exchange.

Keynes' contribution and influence in his times was almost boundless. He used scholarly methods to prove the necessity of state interventions into the economy with the positive impact on aggregate demand (of consumptions and investment) and on employment. In the field of the quantity theory of money, his major contribution, among others, is the different concept of money and its forms based on its liquidity. Keynes was the first to lay the claim of dividing money based on money demand into particular aggregates according to the level of their liquidity ${ }^{9}$. At present, work with monetary aggregates is an inseparable part of the execution of the monetary policy of central banks. They monitor not only the absolute volume of particular aggregates, but in particular the changes and transfers among them.

A part of Keynes' heritage closely related to the theory of money is also a modified concept of the quantity equation of money, the so-called Cambridge equation of equilibrium ${ }^{10}$. In the Cambridge equation, Keynes focuses more on money demand than on money supply governed by central banks. Particular equations also differ in the concept of the aggregate of the velocity of money turnover V. In the classical quantity equation of equilibrium, associated with Fisher, money circulates at a relatively fixed rate and serves rather as a medium of exchange. On the contrary in the Cambridge equation, money acts as a store of value and its velocity of turnover depends on the desirability of households to keep cash. Economists associated with Cambridge University, besides Keynes for example Alfred Marshall, A.C. Pigou and others prove that a certain portion of issued money will not be used for transactions; but is, for the canniness and security purposes, kept by households in cash. This portion of cash is commonly represented as $\mathrm{k}$ and if it is regarded in a short-term period as fixed, then according to the Cambridge equation the velocity of money turnover $\mathrm{V}$ equals to the inversion value of $\mathrm{k}$. The Cambridge equation is thus:

$$
\mathrm{M} \cdot 1 / \mathrm{k}=\mathrm{PQ}
$$

The development of economic thinking in the last third of the $20^{\text {th }}$ century was significantly influenced by the so-called Chicago school of economics which began focusing on the quantity theory of money from the monetary point of view. This monetary stream led into the movement represented by the principal

9 KEYNES, J. M. Obecná teorie zaměstnanosti, úroku a peněz. Praha: Československá akademie věd, 1963, s. 129.

10 KEYNES, J. M. The General Tudory of Employment, Interest and Money, Chapter 2: The Postulates of the Classical Economics, 2012, s. 183. 
representative of the liberal economic theory and of the Laissez faire doctrine Milton Friedman.

Keynes' relation between the volume of money and other quantities in the transaction equation is not as simple as it may seem. The quantities are affected by many, already mentioned, factors - liquidity of money, devaluation of money due to inflation, unemployment, consumers' preferences, etc. Monetarists find this relation more direct. In case the economy is not suffering from intense changes and consumers' preferences are stable as the result of stable expectation of future revenue, and the velocity of money turnover $\mathrm{V}$ (the ratio of gross domestic product and the amount of money, i.e. GDP/M) is relatively fixed, then it is possible to influence prices and therefore the economic activity through the supply of money M. Friedman formulated this clearly in a range of his papers and works, such as in the paper "The Role of Monetary Policy" from 1968, "The Optimum Quantity of Money: And Other Essays" from 1976, "Monetary Policy: Theory and Practice" from 1982 and in many others.

\section{Monetary Aggregates}

The mutual correlation between the growth of the price level $\mathrm{P}$ and the increase of money supply $M$ was proved by lots of research work performed independently of each other in many advanced countries. If price stability is to be kept, which is the main aim of central banks' activities at present, the principal target is to maintain an equable growth of money supply and also a growth of production. In other words: there is inflation if the left side of the equation, or the growth of money supply (on condition that the velocity of money turnover $\mathrm{V}$ is fixed), advances the right side of the equation, i.e. the growth of a product (offered goods and services) ${ }^{11}$. In his paper "Inflation: Causes and Consequences" from 1963, Friedman describes that inflation is always and everywhere a monetary phenomenon.

Together with the establishment of this new economic concept of the quantity theory of money and inflation, these thoughts were increasingly brought to the notice of operative activities and monetary policies of central banks. Recently this has been facilitated by the boom of information technologies which enable modelling economic processes, or the relation of the above mentioned quantities, while putting emphasis on the supply of money in circulation and its impact on inflation, by means of various economic-mathematical models.

Experience shows that at present central banks pay an extraordinary attention to the volume of money supply. The main issue they have been facing is how to determine the volume of the money supply part which a bank uses for the application of its issuing and corrective policy. This takes us back to the

11 FRIEDMAN, M. The Role of Monetary Policy. In Američan Economic Review. Vol. 58, No. 1, 1968, s. 44. 
above mentioned fact of different liquidity of different forms of money which are cumulatively and for the purpose of monetary equilibrium equation defined as the aggregate $\mathrm{M}$. Central banks apply methodical and structural distinction of the aggregate $\mathrm{M}$ into its particular elements which are carefully monitored with regard to their absolute amount as well as to the mutual transfer of their volume. The aggregate M1 is sometimes used for transaction money (narrow money), it is the most significant and the most monitored aggregate. According to the methodology of the Czech National Bank, M1 includes money in circulation (i.e. banknotes and coins) as well as the balance which can be immediately transferred to money in circulation or used for cashless payments, e.g. one-day deposits. This is the most liquid monetary aggregate. The aggregate M2 comprises of the aggregate M1 and moreover of the deposits due within two years and the deposits which are subject to three months' notice. Depending on liquidity, these deposits may be transferred to the elements of narrow money but in some cases there may be some restrictions such as the necessity of terminating the deposit by a notice, delay, penalty or charges. The definition of the aggregate M2 reflects the interest in analysing and monitoring the monetary aggregate which besides money in circulation includes also liquid deposits. The aggregate M2 is called quasi money (near money). The same procedure may be used to create other aggregates in an analytical way with lower and lower rate of liquidity. The aggregate M3 consists of the aggregate M2 and of tradable tools issued by monetary financial institutions. This aggregate includes some tools of monetary market, particularly shares and investment certificates of market funds and repos. A high level of liquidity and price security guarantee that these instruments are near substitutes of deposits even though their liquidity is considerably lower. Incorporation of these instruments leads to the fact that the aggregate M3 is affected by substitution among different categories of liquid assets less than the narrower definitions of money are, and therefore it is more stable. The aggregate M3 is called broad money. The aggregate M4 consists of the aggregate M3 and of deposits in domestic non-bank institutions (e.g. co-accepted drafts and cheques). The aggregate M5 includes the aggregate M4 and other securities in the domestic currency (e.g. long-term obligations or bonds).

Why are central banks watching the particular aggregates so carefully? Simply because the amount and change of volume of particular aggregates are significant indicators of the economic performance of economy. A transfer of money from the aggregate M1 to the aggregate M2 signals increased saving behaviour in the economy. The increased volume of the aggregate M2 is for commercial banks the main source for giving credits. Increased but cautious crediting of enterprises by banks means an increased investment activity but also an increased flow of money to enterprises in other forms (financial means for operation, export etc.). Many analyses proved that the increase of the aggregate M2 is, after a particular lapse of time, followed by the growth of GDP. A fast growth of this form of 
money accompanies a boom, its restriction is on the other hand often followed by recession, or can even have worse effects.

Analytical monitoring of particular monetary aggregates is also an inseparable part of the monetary policy of central banks, especially in their activity related to inflation targeting; despite the fact that the development of monetary aggregates does not directly enter into the prognoses, e.g. of the Czech National Bank. The reason for this is that in the mode of inflation targeting, when the central bank checks the interest rates and withdraws excess money from the market, the development of money supply only reflects the economic development, measures of monetary policy and expectations of economic entities. Monetary aggregates may still serve as additional indicators for verifying the prognosis if they carry information about the current or future development of the economy. The analysis of the predicative ability of the monetary aggregates using the indicators of the so-called monetary overhang and the nominal and real monetary reserve is also a part of monetary policy analyses. These concepts are commonly used for analysing the monetary aggregates also by the ECB.

The monetary overhang is defined as a percentage deviation of the real level of money supply from the level corresponding to the current position of the economy within the cycle and other fundamentals; and it is calculated based on a standard estimate of money demand. The nominal monetary gap is defined as a percentage deviation of the real aggregate M2 from the value it would have reached if it had grown at the rate reflecting the potential of the economy and the inflation target. The real monetary gap is defined as the nominal monetary gap adjusted by the difference between the real inflation and the inflation target. The monetary gap differs from the monetary overhang by the fact that in case of the monetary overhang the analysis is focused on how much the dynamics of M2 corresponds with the current development of the economy, while in case of the monetary gap the analysis is focused on how much the development of M2 corresponds with long-term equilibrium trends in the economy.

As it is difficult to divide the aggregate $\mathrm{M}$ into its particular elements according to a qualitative methodological point of view, it is also difficult to determine the optimum volume of these elements. This depends not only on the decisions of central banks but also on the particular economic situation of the country, on the priorities of the government and on its economic policy, on the structure of the state budget or on the state of the banking sector in the country. The practical application of the monetary policy thus depends on the priorities which are set in the particular country for the future status of national economy. Therefore it is not simple to analyse and compare monetary aggregates of different countries. At the end of the year, the central bank may determine the so-called target corridor of money supply, e.g. by dividing the year into four quarters and comparing the planned and expected amount of money supply with the previous year. This may be used for continual refinement of monetary policy targets, even several 
times a year. For refining future prospects, a wide range of information is taken into account, namely e.g. the current status of the economy, its growth or decline, pressures on price increase, exchange rate changes, commodity prices and many other facts, even those which are difficult to be estimated at that time.

Assessment of the aggregate $\mathrm{M}$ by central banks in an isolated way, without mutual relations and without respecting mutually different functions of money, does only little predicate about the particular status and fulfilling the issuing policy of the central bank. Money in the form of capital, which brings product and further revenue, income, wages and taxes into the state budget has a completely different function in monetary circulation than money in the form of money in circulation which only enables the exchange and consumption of the goods produced. Both are money of the aggregate $\mathrm{M}$ but with completely different monetary functions and consequences.

Central banks cannot simply replace deficit production of the economy or for example deficit of the state budget by new issue of cash money. Such issue would be unfair and harmful - it would give purchasing power to the first holders of this money as well as to those who do not participate in production and moreover, inflation consequences of this excess issue of money would destroy the purchasing power of all economic entities. At present, central banks take this fact into account when issuing money and use suitable regulatory measures and tools which allow governing money circulation not only as a global monetary mass but with respect to the differentiation of various forms of money and monetary functions of particular elements of the monetary aggregate.

\section{Conclusion}

At present the care of price stability is the main objective of the monetary policies of central banks in advanced countries. Exactly the same objective is set for the Czech Republic by Article 98 of the Constitution of the Czech Republic and Paragraph 2 of the Czech Act No. 6/1993, on the Czech National Bank. The same objective, i.e. price stability, is set for the European Central Bank in Article 105 of the Treaty on the Functioning of the European Union. The Czech National Bank also supports the general economic policy of the government if this side objective is not counter to its main objective. Securing price stability in the economy, i.e. to contributing towards creating a stable business environment, is a part of the central bank liability for sustainable economic development. The Czech National Bank endeavours to fulfil this through the monetary policy mode called inflation targeting.

The Czech National Bank, similarly to most of the central banks, concentrates mostly on the stability of consumer prices. Practically, price stability does not mean changelessness of prices but their slow increase. The increase of prices corresponding with price stability should include a statistical deviation upwards 
which occurs at measuring the increase of prices, and should also give the necessary scope for slight changes of price relationships which happen in every economy with an effective price system all the time.

At present, the dominant activity of central banks related to the monetary policy is primarily establishing interest rates and executing operations on the free market. The issuing activity of central banks is often being marginalized. Nevertheless, the possibilities of central banks to influence the performance of the economy through the interest rates are quite limited. Commercial banks secure their sources first of all on the primary market, or by means of trade among themselves on the bank-to-bank market and the policy of central banks is effective only little. This can be seen even at present when the policy of minimum rates established by central banks is not able to support the economy and its growth.

On the other hand, a competent issue of money and regulation of the monetary aggregate $\mathrm{M}$ represents a more efficient monetary policy tool aiming at economic recovery and sustainable growth. Central banks must carefully analyse also the internal structure of the aggregate $\mathrm{M}$, consisting of the aggregate $\mathrm{M} 1$ to M5, and adjust also other tools from a wide range of monetary policy instruments. Central banks must be prospective in their issuing activity because an excess issue of money in its consequence always leads to the increase of prices and its impact on the real product in a long-term perspective is none.

To sum it up, it is clear that

- inflation is a monetary phenomenon which follows rather from faster increase of the amount of money (left side of the transaction equation) than by the product (right side of the transaction equation),

- there is only one efficient treatment of inflation, which is a lower rate of money supply growth (executed by different monetary policy tools),

- treatment of inflation is long-term and the costs of disinflation are always high, mostly related to the decline of the product growth dynamics and to the increase of unemployment.

Acknowledgement: Work on this paper was supported by the grant from Faculty of Arts, Palacký University, IGA FF_2015_014, Continuities and Discontinuities of Economy and Management in the Past and Present. 